\title{
Further Studies on Genetics and Cytology of Artificially Raised Interspecific Hybrids of Prencerer.
}

Contributions to Cytology and Crenetics from the lepartments of PlantMorphology and of Genetics, Botanical Institute, Faculty of Science, Tokyo Imperial University, No. 67

By.

\section{K. Yasui}

With 1t Text-Figures

The artificialiy raised $F_{1}$ plants I'apauer somniforum $L_{\text {. }}$ var. glabrum IBors. $\times I^{\prime}$. mudicaulc $\mathrm{L}$. were selfed in some hundred cases, which produced almost no seed. The microscopical examination showed that the pollen grains were sterile, and the female gametes almost entirely sterile, having an extremeiy small percentage of seed production. This small partial fertility was used for the study of the distribution of paternal characters in the offsprings and the karyological behavior accompanying them.

The present repori will briefly deal with some genetical data concerning 3 successive generations, and their cytology with special reference to the chromosome number and its behavior.

\section{MATHRIAI, ANI MF:THOI)}

The parent plants used in the experiments were Papaver somniforum L. var. glabrum Bors. and Papaver nudicaulc L., the forme being of the same pedigree with the plants used in the experiments of my previous paper on Papaícr hybrid (YASLI, 1921).

The characters of $I^{\prime}$. mudicaule $\mathrm{L}_{1}$. which were taken into consideration in the present experiment are as follows: perennial slender herb, hairy stem and leaf, waxy green pinnately cut leaf; sepals two as a rule, sometimes three; petals generally 4, occasionally 6 , sclmon orange to grendine; stamens yeilow with purplish white filaments; and the capsule elongated with purple stigma.

In autumn 1921 the seeds of Papaver nudicaule L. from the Botanic Garden of Tokyo Imperial University were sown. The plants flowered in spring 1922, and were used as male as weil as 
female parents of the hybrid. They were selfed too, and the $S^{1}$ plants flowered in 1922, and were found to show all the characters in consideration constant.

The $F_{1}$ plants were selfed and back-crossed with pollen of both parents.

Fixing and staining. Some material for cytological examinations was fixed with .BFind's solution and stained with Himminain's iron-alum hacmatoxylin, while others were treated according to TAYIOR's smear method (TAYLOR, 1924). The latter proved very successful, especially for the study of chromosome numbers.

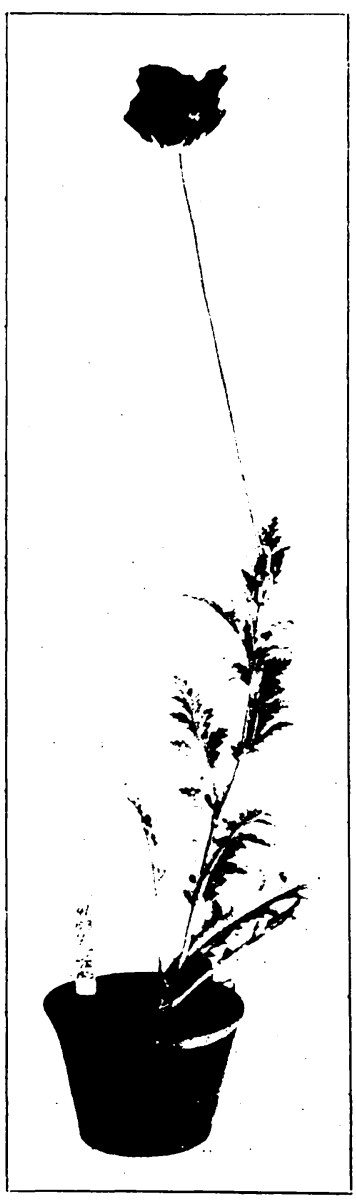

Text-fig. 1. F 1 plant of Papaver somniferum I. var. glabrum BoIs. $\times$ I'. nuidicaule $\mathrm{I}$.. 1,8 nat.

\section{Eixternai, Characters of Fil Plant}

In the reciprocal crossing between $P a$ paver mudicaule $\mathrm{L}$. and $P$. somniferum $\mathrm{L}$. var. glabrum Bors., P. somniferum $\mathrm{I}_{1}$. var. glabrum BoIs. $\times I^{\prime}$. mudicaule $\mathrm{L}$. only gave seeds, so that the present descriptions are limited to the $F_{1}$ plants of the latter crossing. Text-fig. 1 is a photograph of one of $F_{1}$ plants. They are characterized by the following points :

1. $F_{1}$ plants germinated in autumn 1922 and flowered in the next spring and died away in the summer, i. e. the plant is annual, and the perennial character of the male parent is recessive to the annual character of the female parent, contrary to the case of the hybrid between $P$. somnif crum $\times P$. mudicaule (YASUI, 1921).

2. $F_{1}$ plants were tall like the female parent, but neither so stout as the latter, nor so slender as the male parent ; branched several times as in the male parent. The shape of leaves were intermediate between those of both parents. The stem and leaves were hairy, but not so thick as in the male parent, with somewhat waxy surface like those of the female parent.

3. Flowers were all single, while the doubleness of the flower of the female parent was dominant to the singleness in the case 
of the hybrids among the races of $I^{\prime}$. somnifirum var. glalmum

4. Color of the petals was scarlet in all cases of the lyybrids, the white, pink, purple and deep red of the female parents, having no apparent influence for the color of tite hybrid. The purple color of the filament and the yellow anther of the male parent were dominated in the hybrids.

5. The capsules of all $F_{1}$ plants were roundish somewhat like that of the female parcnt, thongh not so large as in the latter.

6. The pollen errains were irregular in sizes, most of them being sterile. Some hundreds of flowers of $F_{1}$ plant were selfed during 1922-1926, but no fruits were obtained, but one capsule which was gathered in 1926.

\section{CyTOLOGY OF Fi PIANTS}

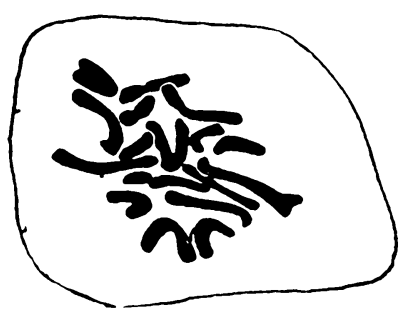

Text-fig. 2. Metaphase chromosomes of a regetative cell of an ovule of $F_{1}$ plant.

P. somniferum I. var. glabrum Bors. has 22 diploid chromosomes as 'TAHARA (1915) has shown, and I'. nudicauli L. 14 as IJUNGDimL (1924) has described.

$F_{1}$ plants have $11+7=18$ chromosomes in their vegetative cell (Text-fig. 2) and the pollen mother-cell. After second contraction in the meiotic phase of pollen mother-ceils 6 or 8 chromosomes formed gemini, so that there were 3 or 4 bivalent chromosomes or bivalents (or bivs.) and 10 or 12 univalent chromosomes or univalents (or univs.) in a pollen mother-cell, and the chromosomes in gemini jointed end to end, and never parallel (Text-fig. 3, a and b).

'The bivalent chromosomes formed equatorial plate first, while the univalent chromosomes are scattered around them ('Text-fig. 3, b). When the bivalent chromosomes cntered into anaphase univalent chromosomes enter into equator and undergo longitudinal division, and each halves of them follow the course of bivalent chromosomes (Text-fig. 3, c). In this case, all univalent chromosomes did not enter into the equator simultaneously, so that some chromasomes are often excluded from the nucleus, forming extra chromosomes or divarf nuclei (Text-fig. 3, d), when the nuclear membrane formation, after the 1st nuclear division of the meiosis, took place, as is the case with the meiosis of $F_{1}$ plants of $P$. somnif crum $\times P$. oricntalc, though in the former the irregularities are greater than in the latter.

The second division of mreiosis is also irregular, more than four pollen grains being formed as its result in each pollen mother-cell 

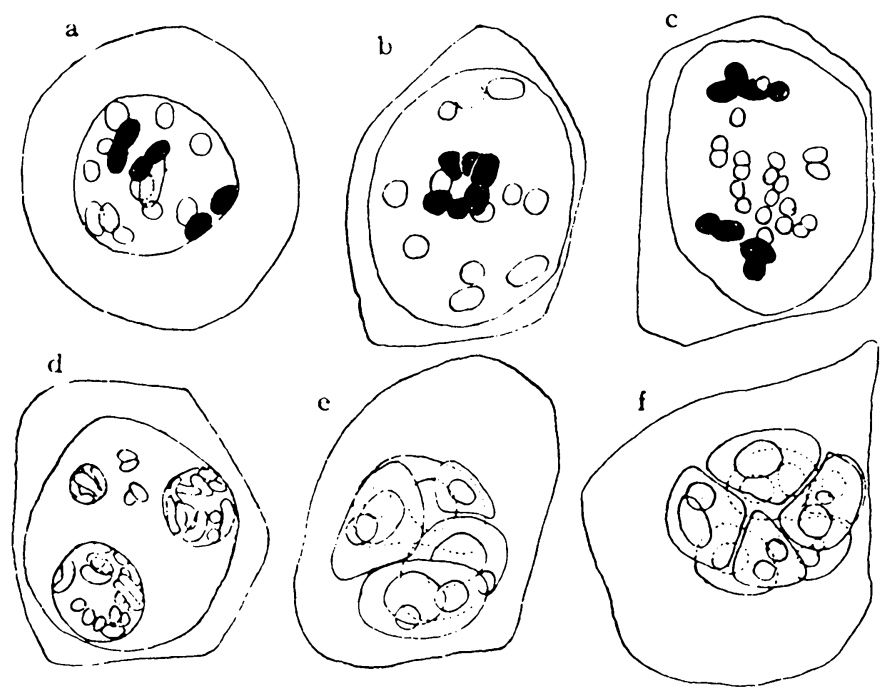

Tert-fig. 3. Pollen wother-cells in $\mathrm{F}_{1}$ plant. a, liakinesis, 3 bivalent (black) and 12 univalent (hlank) (hromosones are seen ; h, metaphase of bivs., 12 univs. heing scattered outsile of them; c, chromosome garniture with 4 bivs. at each pole and 12 unirs. occupying the central region; d, interkinesis, 2 large nuclei, one smaller nucleus and 2 extra nuclear chromosomes are seen; e, pollen mothercell with 4 large pollen grains, each with an extra nuclear chromosome, and one small pollen grain; f, a pollen mother-cell with s pollen grains, some of them with extra nuclear chromo:omes.

as in the case of $I^{\prime}$. sommif $(r) m \times I^{\prime}$. oricntalc, but the irregularities here are greater than in the latter ('Text-fig. 3, e and f).

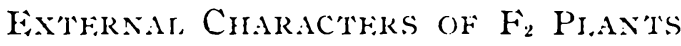 \\ (BACK-CrOSSNI) Fl PIANTS)}

In 1924 several flowers of $F_{1}$ plants were pollinated with the pollen grains of the female parents. Generally only one or two, sometimes no seeds were obtained from each capsule. 'The seeds were sown in autumn of the year, and about 60 seedlings were raised. They flowered in next spring, and were characterized as follows:

1. Stems were thicker than that of $F_{1}$ plant, but not so stont as that of $I^{2}$. somnifirum var. glabrum.

2. 'The shape of the leaves was very much like that of $I$ '. somnifcrum var. glabrum.

3. The surface of the stem and leaves was waxy and not so much hairy as that of $F_{1}$ plant.

4. The color of the petal in ail but one individual $(41,15,15,52)$ was just the same to that of $F_{1}$ plant. 
5. The color of the petal of the aberrant individuals just referred to was phlox with paler margin and a purple patch at the base, and the shape of the flower was also similar to that of $P$. somnif crum I. var. glabrum Bors.

6. There was one individual $(41,15,15,3)$ among all, which had double flowers.

\section{Cytology of F., Plants}

Only 4 individuals of the back-crossed $F_{2}$ plants were studied cytologically, and they showed the following chromosome behavior;

1. $41,15,15,57.11$ bivalent and 5 univalent chromosomes were found in the pollen mother-cells (Text-fig. 4, a). In the first division of the meiosis 11 bivalent chromosomes enter into the
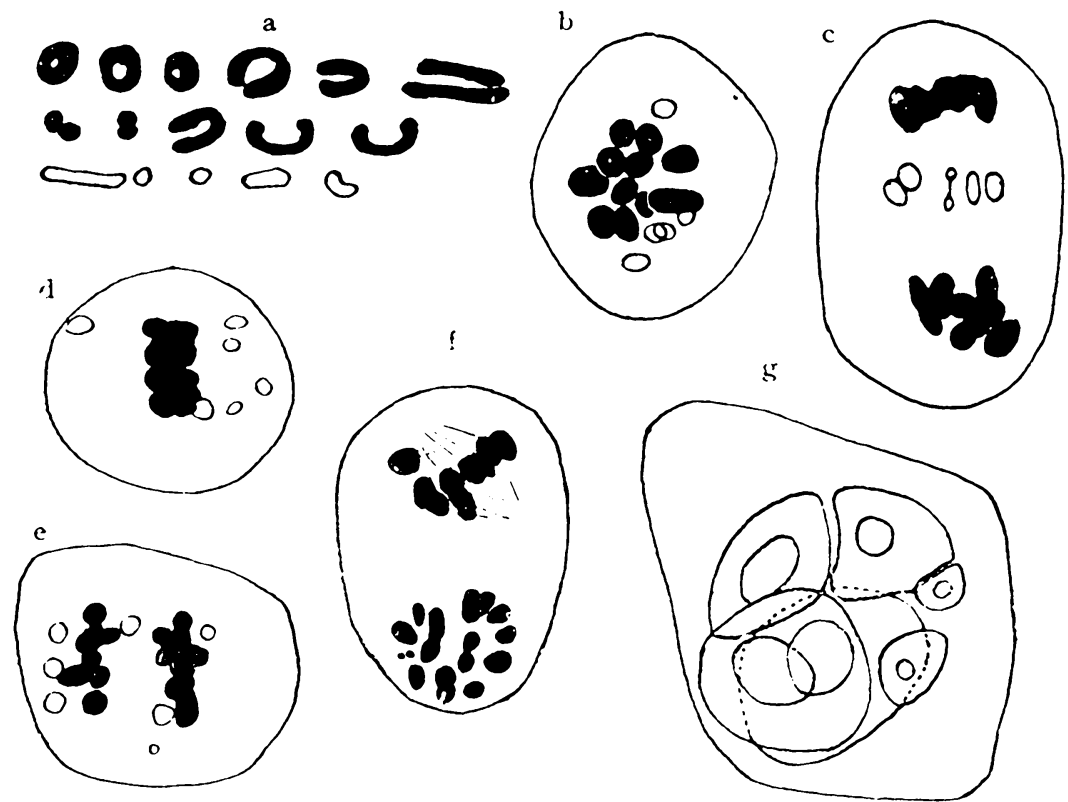

Text-fig. 4. a, chromosome in diakinesis of pollen mother-cell of $F_{2}$ (back-crossed $F_{1}$ ) piants, 11 bivalent (black) and 5 univalent (blank) chromosomes; b-g, pollen mother-cells of $F$, plant; $b$, polar view of metaphase of bivs. (11 pairs), 5 univs. scattered outside of them; c, later stage, from the material derived from the same flower; d, bivs. in metaphase (!)lack) an:l 6 univs., the 7 th is not seen in this figure (blank); e, the later stage, observed in the same material; f, homotypic division, 12 large chromosomes and two smaller chromosomes seen in the polar view of the metaphase; $g,+$ large pollen and two smaller pollen grains in a pollen mother-cell.

equator first, while the univalent chromosomes remain outside (Text-fig. 4, b). As each halves of bivalent chromosomes leave the 
equator for the poles, the univalent chromosomes now get into the equator, and they divide longitudinally and each halves of them follow the bivalent chromosomes to pole (Text-fig. 4, c).

2. $41,15,15,1$. 11 bivalent and 6 univalent chromosomes were found in the nucleus of the pollen mother-cell. Among the former 4 pairs were ring-shaped, one pair in side by side, and other three in an end to end arrangement in diakinesis.

3. $41,15,15,58$. No first division of the meiosis was observed, but in the second division one nucleus showed 14 cliromosomes ('Text-fig. 4, f), and more than 4 pollen grains, even 6 , were found in cach pollen mother-cell ('iext-fig. 4, g). The latter case suggrests the irregular benavior of the meiosis.

4. $41,15,15,3.11$ bivalent and 7 univalent chromosomes were found. The 11 bivalent chromosomes form the equatorial plate first and the course of the univalent chromosomes and the irregular behavior of the chromosomes were similar to the case described above ('Text-fig. 4, d-e).

In comparing of these irregularities in $\vec{F}_{2}$ plants with that of $\mathrm{F}_{1}$ plants, the former were always less irregular than the latter, and many ring-shaped bivalent chromosomes were found in $F_{2}$ plants, but never in the case of $F_{1}$ plant.

\section{F: PIANTS}

Among about 60 back-crossed $F_{2}$ plants 19 individuals gave seeds by self-pollination. The main points of the external characters and the chromosome behavior in the meiosis of pollen mother-cells are shown in the following 6 divisions I-VI.

I. In this, the female parent of $F_{1}$ plants had the single flower, pale purple petal with a deep purple patch at the base. The $F_{1}$ plants were back-crossed with the pollen of a plant belonging to the female parent type, and from this three pedigrees (1-3) were detived.

Pedigree 1. $F_{3}$ plants $41,15,27$ ( $S_{1}$ of $F_{2}$ plant $41,15,15,52$, which closely resembled the female parent of $F_{1}$ plant, but with petals slightiy tinged with pink).

The external characters of the flowers of more than 50 individuals were examined and found to agree with each other and similar to the female parent of $F_{1}$ plant.

The results of karyological cxamination in the meiotic plase of pollen mother-cells in 14 individuals are as follows: 
Table 1

\begin{tabular}{|c|c|c|c|}
\hline J)ivision & Chromosome num!er & $\begin{array}{l}\text { Number of in- } \\
\text { dividlual plants }\end{array}$ & Total \\
\hline Regular & $\begin{array}{l}11 \text { bivs. } \\
\text { Un letermined }\end{array}$ & $\begin{array}{ll}9 & \\
2 & \end{array}$ & 10 \\
\hline Irregular & $\begin{array}{l}11 \text { bivs. }+2 \text { univs." } \\
11 \text { bivs. }+1 \text { univ. } \\
\text { Envletermined? }\end{array}$ & $\begin{array}{l}1 \\
1 \\
2\end{array}$ & 4 \\
\hline Mostly irregular & 11 livis. ${ }^{3)}$ & 1 & 1 \\
\hline
\end{tabular}

1) Meiosis irregular, $2-4$ or more pollen grains being formed in a pollen mothercell ('Text-fig. 5, c).

2) 2-4 or more pollen grains formed in one pollen mother-cell.

3) In addition to the pollen mother-cells with the normal tetral division there are some in which homotypic division is omittel, so that only two pollen grains are formed (Text-fig. 5, e); there are also the cases in which only one of the daughter nuclei of the first division, resulting in the formation of 3 pollen grains in one pollen mother-cell.
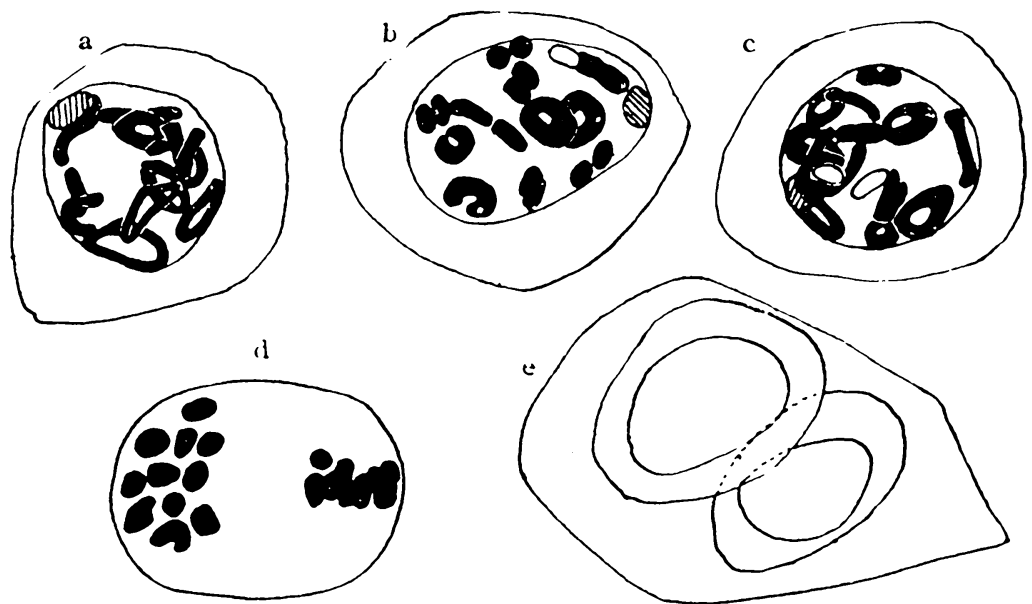

Text-fig. 5. Pollen mother-(ells of $I: a$ plant (Pedigree 1). a, liakinesis, 11 bivs. seen ; b, diakinesis, 11 biss. and one unirs. seen; c, diahineris, 11 birs. and 2 unirs. seen ; d, metaphases of homotypic division, 11 bivs. and one unv. se.n ; e, polle mother-cell in which only 2 pollen grains are formerl.

Pedigree 2. $F_{3}$ plants $41,15,29\left(\mathrm{~S}_{1}\right.$ of $\mathrm{F}_{2}$ plant $41,15,15,1$, whose flower was similar to that of $F_{1}$ plant).

Tile external characters of the flowers of $F_{3}$ plants were sim:lar to that of the female parent of $F_{1}$ plant except 2 , one of which the petals tinged slightly with pink, and the other lad petals which were in deeper color than the others. 
The results of karyological examination in the meiotic phase of pollen mother-cells of 13 individuals are as follows:

Table 2

\begin{tabular}{|c|c|c|c|}
\hline J)ivision & Chromo:ome number & $\begin{array}{l}\text { Number of in- } \\
\text { diviclual plants }\end{array}$ & Total \\
\hline Regular & $\begin{array}{l}11 \text { bivs. } \\
\text { Indetermined }\end{array}$ & $\begin{array}{l}6 \\
4\end{array}$ & 10 \\
\hline Irregular & $\begin{array}{l}11 \text { bivs. }+1 \text { biv. or } 2 \text { univs. } \\
11 \text { bivs. }+1 \text { univ. } \\
\text { Endeterminedl) }\end{array}$ & $\begin{array}{l}1 \\
1 \\
1\end{array}$ & 3 \\
\hline
\end{tabular}

1) 2-3 pollen grains formed in one pollen mother-cell.

a

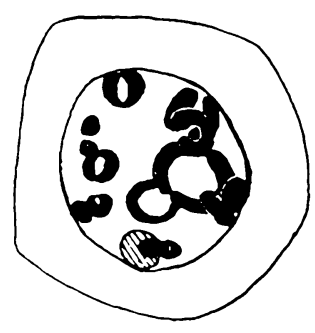

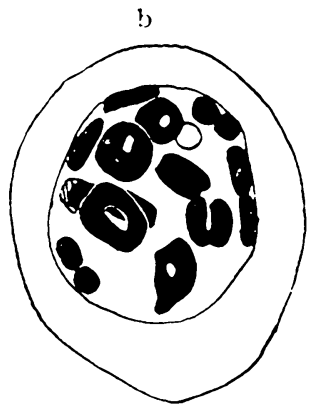

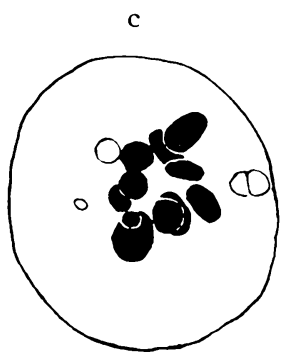

Text-fig. 6. Three pollen mother-cells of $F_{3}$ plants (Perligree 2). a, diakinesis, showing 11 bivs.; b, diakinesis, 11 bivs. and one univ. seen; c, metaplase of 11 birs., 3 unirs. scatterel outsicle of them.

Pedigree 3. $\mathrm{F}_{3}$ plants $41,15,30\left(\mathrm{~S}_{1}\right.$ of $\mathrm{F}$ : plant $41,15,15,2$, whose flower resembled that of $F_{1}$ plant).

The external characters of the flowers of $F_{3}$ plants were similar to each other and to that of the female parent of $F_{1}$ plant, except one which had deep purple petals.

The results of karyological examination in the meiotic phase of pollen mother-cells of 7 individuals were that the division was regular, and 11 bivalent chromosomes were found in all individuals.

II. The female parent of $F_{1}$ plant had the double flower, the entire red petal with white patch at the base. The $F_{1}$ plant were back-crossed with the pollen of $P$. somnif crum var. glabrum, which had the single flower and the laciniated red petal with a purple patch at the base; and 6 pedigrees (4-9) were derived from this.

Pedigree 4. $\mathrm{F}_{3}$ plants $41,15,31\left(\mathrm{~S}_{1}\right.$ of $\mathrm{F}_{2}$ plant $41,15,15,3$, which was only plant having double flower among the back-crossed 
$\mathrm{F}_{2}$ plants. The colour of the flower was similar to that of $\mathrm{F}_{1}$ plant). The external characters of the flowers of 29 individuals examined are shown in Table 3.

Table 3

\begin{tabular}{|c|c|c|c|}
\hline \multicolumn{2}{|c|}{ Character } & $\begin{array}{l}\text { Red petal with a } \\
\text { purple patch }\end{array}$ & $\begin{array}{c}\text { Red petal with a } \\
\text { white patch }\end{array}$ \\
\hline \multirow{4}{*}{\multicolumn{2}{|c|}{$\begin{array}{l}\text { Ifaciniated } \ldots\left\{\begin{array}{l}\text { single } \\
\text { double }\end{array}\right. \\
\text { Intire } \ldots \ldots\end{array}$}} & 10 & 5 \\
\hline & & 1 & 2 \\
\hline & & 5 & 5 \\
\hline & & 1 & 0 \\
\hline
\end{tabular}

Purple patch: white patch $=17: 12$

Laciniated : entire $=18: 11$

Single: double $=25: 4$

The results of karyological examination in the meiotic phase of pollen mother-cells in 6 individuals are as follows:

Table 4

\begin{tabular}{|c|c|c|c|}
\hline Division & Chromosome number & $\begin{array}{l}\text { Number of in- } \\
\text { dividual plants }\end{array}$ & 'Total \\
\hline Regular & 11 bivs. & 0 & () \\
\hline Irregrular & $\begin{array}{l}11 \text { birs. }+3 \text { univs. } \\
11 \text { bivs. }+2 \text { univs. } \\
11 \text { bivs. }+1 \text { univ. } \\
\text { Endeterminerl }\end{array}$ & $\begin{array}{l}1 \\
1 \\
2 \\
2^{11}\end{array}$ & 6 \\
\hline
\end{tabular}

1) One of them had 2-t pollen grains in one pollen mother-cell.

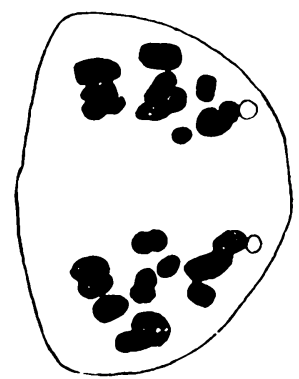

b

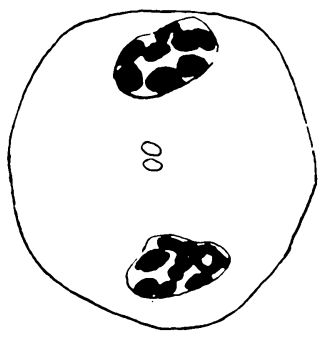

'lext-fig. 7. 2 pollen mother-cells of $F_{3}$ plants (Pedigree 4). a, heterotypic anaphase, showing the garniture of 11 chromosomes (black) derived from bivs. together with one chromosome derived from univ. at each pole; b, a divided univ, at the equator, being excluiled out of daughter nuclei at the poles. 
Pedigree 5. $\quad F_{3}$ plant $41,15,32\left(S_{1}\right.$ of $F_{2}$ plant $41,15,15,4$, whose flower resembled that of $F_{1}$ plant).

The external characters of the flowers of 24 individuals examined are shomn in Table 5.

Table 5

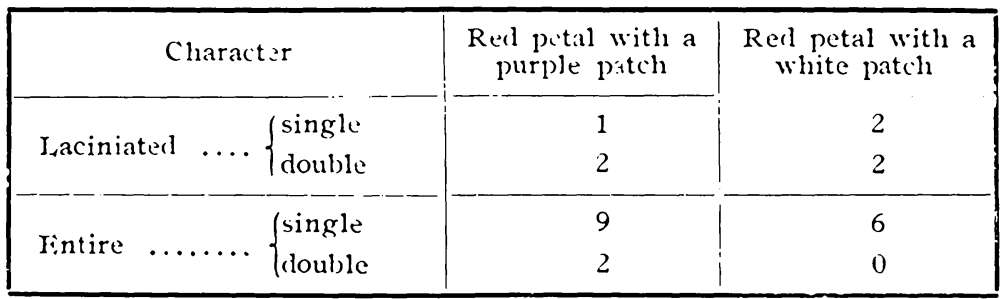

Purple patch: white patch $=14: 10$

Single : doule $=18: 6$

Laciniated: entire $=7: 17$

The results of karyological examination in the meiotic phase of pollen mother-cells in 9 individuals are as follows:

Table 6

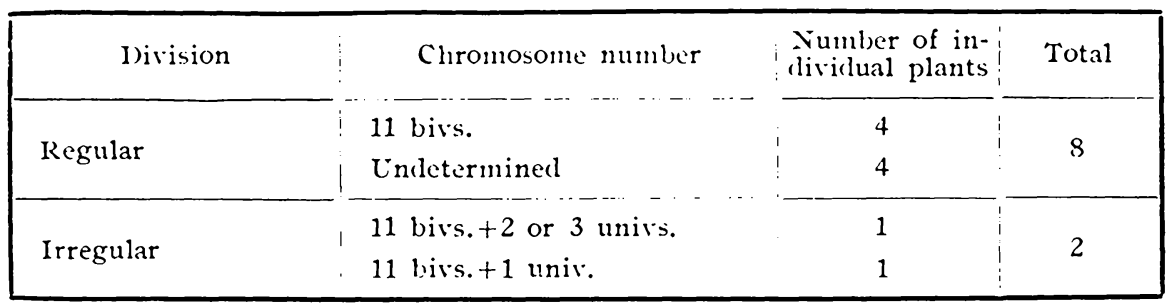

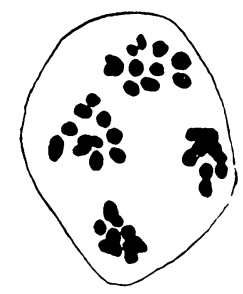

'lext-fig. 8. Pollen mother-cell of $\mathrm{F}_{3}$ plant (Pedigree 5), showing regular homotypic division.

Pedigree 6. $F_{3}$ plants $41,15,38^{\circ}$ ( $S_{1}$ of $F_{2}$ plant $41,15,15,10$, whose flower resembled that of $F_{1}$ plant).

The external characters of the flowers of 25. individuals examined are shown in Table 7 : 
'iable 7

\begin{tabular}{|c|c|c|}
\hline Character & $\begin{array}{c}\text { Red pital with a } \\
\text { purple patch }\end{array}$ & \multirow{2}{*}{$\begin{array}{l}\text { Rerl petal with a } \\
\text { white patch } \\
-3 \\
3\end{array}$} \\
\hline fingle & 6 & \\
\hline 1raciniater $\cdots$ \{loub!e & 2 & () \\
\hline |singrie & 6 & 0 \\
\hline$\cdots \cdots \cdot$ Trlouble & 4 & 2 \\
\hline
\end{tabular}

Purple patch: white patch $=18: 5$

Iaciniated : entire $=11: 12$

Single : double $=15: 8$

The results of karyological examination in the meiotic phase of pollen mother-cells in 13 individuais are as follows:

'al)le s

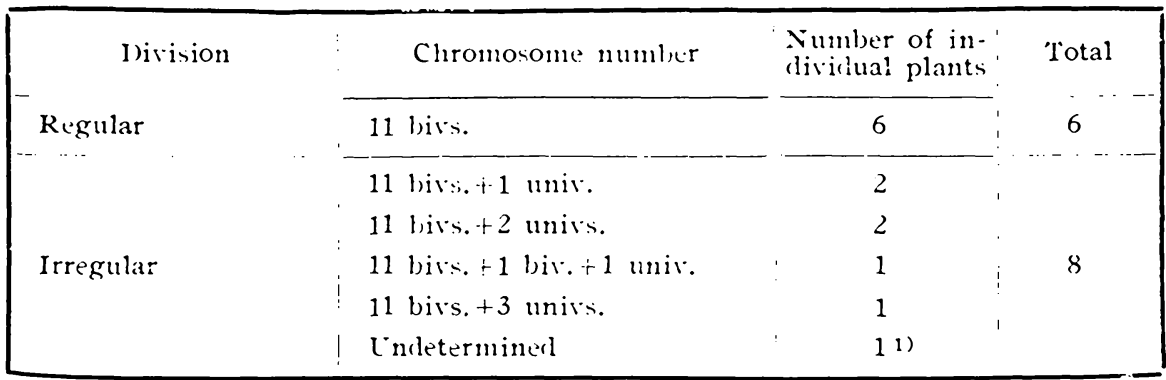

1) 2-4 pollen grain; in one pollen mother-cell.
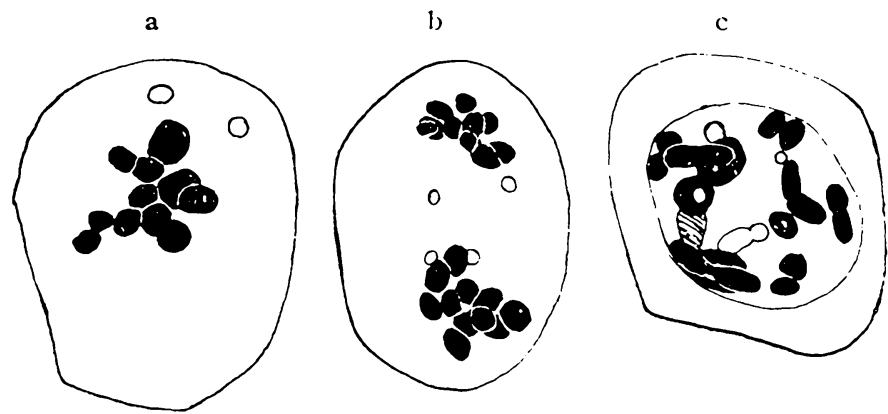

'lext-fig. 9. 3 pollen mother-cells of $F_{3}$ plant (Pedigree 5). a, polar view, 11 birs. (!)lack) at this equator and 2 univs. scattered outside of them; b, side view of a later stage of heterotypic anaphase, chromosome garniture derived from 11 birs. at each pole, and 2 smaller chromosomes, resulting by the eruation division of univs. following them toward each pols; c, diakinesis stage, 11 birs. (black) and 3 unirs. (blank).

Pedigree 7. $F_{3}$ plants $41,15,44\left(S_{1}\right.$ of $F_{2}$ plant $41,15,15.33$, whose flower resembled that of $F_{1}$ plant). 
The external characters of the flowers of 31 individuals examined are shown in Table 9.

Table 9

\begin{tabular}{|c|c|c|c|}
\hline \multicolumn{2}{|c|}{ Character } & $\begin{array}{l}\text { Red petal with a } \\
\text { purple patch }\end{array}$ & $\begin{array}{l}\text { Red petal with a } \\
\text { white patch }\end{array}$ \\
\hline \multirow{2}{*}{ I aciniater } & (single & 15 & 4 \\
\hline & |double & 1 & 1 \\
\hline \multirow{2}{*}{ Fintire } & / single & 7 & 2 \\
\hline & double & () & 1 \\
\hline
\end{tabular}

Purple patch : white patch $=23: 8$

Iaciniated : entire $=21: 10$

Single : double $=28: 3$

The results of karyological examination in the meiotic phase of pollen mother-cells in 6 individuals are as follows:

rable 10

\begin{tabular}{|c|c|c|c|}
\hline Division & Chromosome number & $\begin{array}{l}\text { Number of in- } \\
\text { dividual plants }\end{array}$ & 'lotal \\
\hline Regular & $\begin{array}{l}11 \text { bivs. } \\
\text { Undetermined }\end{array}$ & $\begin{array}{l}4 \\
2\end{array}$ & 6 \\
\hline
\end{tabular}

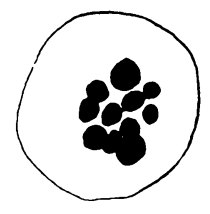

'lext-fig. 10. Polar view of heterotypic metaphase of pollen mother-cell of $\mathrm{F}_{3}$ plant (Pedigree 7 ), 11 bivs. at equator.

Pedigree 8. $\quad F_{3}$ plants $41,15,35\left(S_{1}\right.$ of $F_{2}$ plant $41,15,15,7$, whose flower was the same to that of $F_{1}$ plant).

The external characters of the flowers of 28 individuals were examined are shown in Table 11.

Table 11

\begin{tabular}{|c|c|c|c|}
\hline \multicolumn{2}{|c|}{ Character } & \multirow{3}{*}{$\begin{array}{c}\text { Rerl pital with a } \\
\text { purple patch } \\
13 \\
0\end{array}$} & \multirow{3}{*}{$\begin{array}{c}\text { Red petal with a } \\
\text { white patch } \\
2 \\
0\end{array}$} \\
\hline \multirow{2}{*}{ I aciniated } & (single & & \\
\hline & (louble & & \\
\hline \multirow{2}{*}{ Fintire } & (single & 9 & 3 \\
\hline & $\{$ louble & 1 & 0 \\
\hline
\end{tabular}


Purple patch : white patch $=23: 13$

Laciniated : entire $=15: 13$

Single: double $=27: 1$

The results of karyological examination in the meiotic phase of pollen mother-cells in 6 individuals are as follows:

Table 12

\begin{tabular}{|c|c|c|c|}
\hline I)ivision & Chromo'ome number & $\begin{array}{l}\text { Number of in- } \\
\text { diviclual plants }\end{array}$ & Total \\
\hline \multirow[t]{2}{*}{ Regular } & 11 birs. & 3 & 3 \\
\hline & 11 birs. +2 unirs. & 1 & \\
\hline \multirow[t]{2}{*}{ Irregular } & 11 bivs. 1 or 2 unirs. & 1 & 3 \\
\hline & 11 bivs. + 1 univ. & 1 & \\
\hline
\end{tabular}

Pedigree 9. $F_{3}$ plants $41,15,37\left(S_{1}\right.$ of $F_{2}$ plant $41,15,15,9$, whose flower was similar to that of $F_{1}$ plant).

The extermal characters of the flowers of 34 individuals examined are shown in Table 13.

Table 13

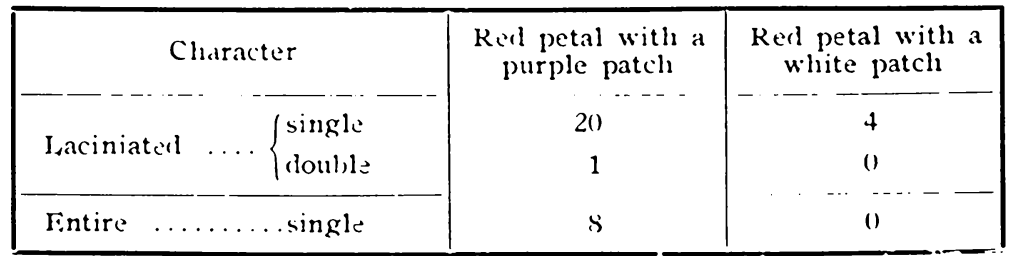

In addition to those showing in Table 13 , there is one inlivilual which had the flower resembled that of $F_{1}$ plant.

Purple patch : white patch $=29: 4$

Laciniated : entire $=25: 8$

The results of karyological examination in the meiotic phase of pollen mother-cells in 6 individuals are as follows:

Table $1 \mathrm{t}$

\begin{tabular}{|c|c|c|c|}
\hline I)ivision & Chromosom? number & $\begin{array}{l}\text { Number of in- } \\
\text { dividual plant }\end{array}$ & \\
\hline Regular & $\begin{array}{l}11 \text { bivs. } \\
\text { Indetermined }\end{array}$ & $\begin{array}{l}4 \\
1\end{array}$ & 5 \\
\hline Irregular & 11 bivs. +2 univs. & 1 & 1 \\
\hline
\end{tabular}


- III. In this, the female parent of $F_{1}$ plants had the double flower, the entire, red petal with a white patch at the base. The $F_{1}$ plants were back-crossed with the pollen of $l$. somnif crum var. glabrum which had the single flower, the laciniated pale purple petal with a decp purple patch at the base, and 2 pedigrees (1-11) were derived from them.

Pedigree 10. $F_{3}$ plants $41,15,40\left(S_{1}\right.$ of $F_{3}$ plant $41,15,15,12$, whose flower was similar to that of $F_{1}$ plant).

The external characters of the flowers of 36 individuals examined are shown in Table 15.

1al1: 15

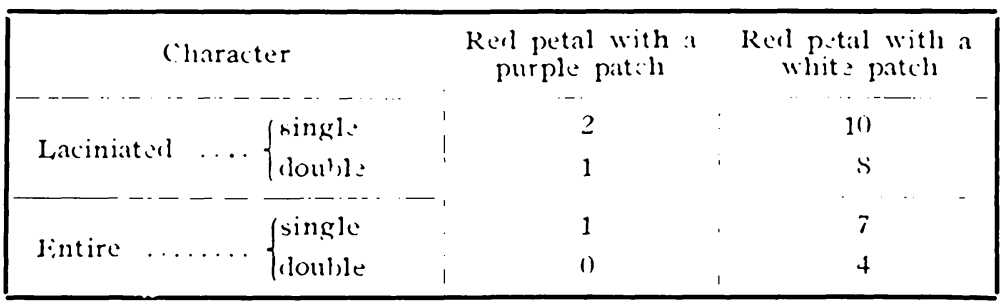

In adclition to those in the above table there wire 3 plants, as follows:

1. The single flower with the leep purple entire petal ....... 2 indivs.

2. The single flower with the laciniatel, purple with a deep?r

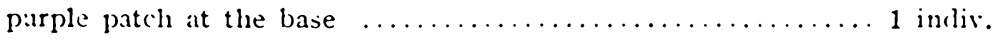

Red : deep purple: pale purple $=33: 2: 1$

Purple patch : white patch $=7: 29$

Laciniated : entire $=22: 14$

Single : double $=23: 13$

The results of karyological examination in the meiotic phasc of pollen mother-cells in 8 individuals are as follows:

Iable 16

\begin{tabular}{|c|c|c|c|}
\hline I)ivision & Chromosome number & $\begin{array}{l}\text { Number of in- } \\
\text { dividual plants }\end{array}$ & rotal \\
\hline Regular & $\begin{array}{l}11 \text { birs. } \\
\text { Undetermin:d }\end{array}$ & $\begin{array}{l}4 \\
2\end{array}$ & 6 \\
\hline Irregular & 11 bivs. +2 univs. & 1 & 1 \\
\hline Mostly irregular & i 11 hivs. & 11 & 1 \\
\hline
\end{tabular}

1) 2-4 pollen grains formed in one poll:n mother-all. 


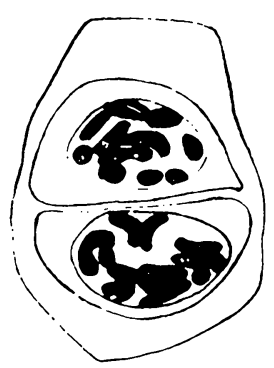

b

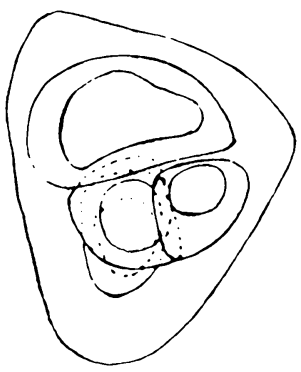

fext-fig. 11. 2 pollen mother-cells of $F_{3}$ plant (Pedigree 10). a, one in which only two polien grains are formed; b, one in which 4 pollen grains are formed, onc of them being unusually large.

Pedigree 11. $F_{3}$ plants $42,15,45\left(S_{1}\right.$ of $F_{2}$ plant $41,15,15,40$, whose flower was similar to that of $F_{1}$ plant).

The external characters of the flowers of 29 individuals examined are shown in Table 17.

rable 17

\begin{tabular}{|c|c|c|c|c|}
\hline \multirow{3}{*}{ Iraciniated . $\left\{\begin{array}{l}-5 i n g l e \\
\text { (double }\end{array}\right.$} & $\begin{array}{l}\text { Red pital with } \\
\text { a purple pitch }\end{array}$ & $\begin{array}{l}\text { Red petal with } \\
\text { a white patch }\end{array}$ & $\begin{array}{l}\text { Purple petal } \\
\text { with a deep } \\
\text { purple patel }\end{array}$ & $\begin{array}{l}\text { White } \\
\text { petal }\end{array}$ \\
\hline & ${ }^{---}$ & $-\cdot$ & $\begin{array}{c}\cdots \\
1\end{array}$ & () \\
\hline & () & 0 & 0) & () \\
\hline I single & 14 & 2 & 2 & 2 \\
\hline lintre..... q louble & 1 & 1 & () & () \\
\hline
\end{tabular}

In allition to those showing in Table 17, there was one which harl the cntire single flower, the purple patch at the lase of petal.

Red : purple : white $=24: 3: 2$

Purple patch: white patch $=23: 6$

Laciniated : entire $=7: 22$

Single: double $=26: 3$

The results of karyological examination in the meiotic phase of pollcin mother-cells in 8 individuals are as follows:

lable 19

\begin{tabular}{|c|c|c|c|}
\hline Disision & Chromosome number & $\begin{array}{l}\text { Number of in- } \\
\text { dividual plants }\end{array}$ & Total \\
\hline \multirow{2}{*}{ Regular } & 11 bivs. & 2 & 2 \\
\hline & 11 bivs. +1 unis. & 3 & \\
\hline 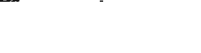 & 11 birs. +2 unirs. & 1 & \\
\hline \multirow[t]{2}{*}{ Irregular } & 11 bivs. +more than 3 univs. & 1 & 6 \\
\hline & Lndetermined & 1 & \\
\hline
\end{tabular}


IY. In this, the female parent of $F_{1}$ plant had the single flower, the laciniated, red petal with a purple patch at the base. The $\mathrm{F}_{1}$ plant was back-crossed with the pollen of $P$. somnifcrum var. glabrum, which had the double flower, and the entire white petal; and one pedigree (12.) was derived from them.

Pedigres 12. $F_{3}$ plants $41,15,24\left(S_{1}\right.$ of $F_{2}$ plant $41.15,15,6$, whose flower resembled that of $F_{1}$ plant).

The external characters of 32 individuals examined are shown in Table 19.

Table 19

\begin{tabular}{|c|c|c|c|c|}
\hline Character & $\begin{array}{l}\text { Red petal with } \\
\text { a purple patch }\end{array}$ & 1)eep purple & $\begin{array}{l}\text { Pale purple with } \\
\text { a purple patch }\end{array}$ & White \\
\hline single & 2 & 0 & 0 & 0 \\
\hline Laciniat ed... \{ double & 0 & 1 & () & 0 \\
\hline (single & 6 & () & 1 & 1 \\
\hline Fintire...$\cdots$ \{rouble & 11 & 4 & 4 & 1 \\
\hline
\end{tabular}

In addition to those in table 19 there was one which had flower resemble! that of $\mathrm{F}_{1}$ plant.

Red : deep purple: pale purple: white $=20: 5: 5: 2$

Single : double $=11: 21$

Laciniated : entire $=3: 29$

The results of karyological examination in the meiotic phase of pollen mother-cells in 11 individuals are as follows:

lable 20

\begin{tabular}{|c|c|c|c|}
\hline Division & Chromosome number & $\begin{array}{l}\text { Number of in- } \\
\text { dividual plants }\end{array}$ & Total \\
\hline Regular & $\begin{array}{l}11 \text { birs. } \\
\text { Encletermined }\end{array}$ & $\begin{array}{l}4 \\
1\end{array}$ & 5 \\
\hline Irregular & $\begin{array}{l}11 \text { bivs. }+4 \text { unirs. } \\
11 \text { birs. }+2 \text { univs. } \\
11 \text { bivs. }+1 \text { unir. } \\
\text { Endeterminer? }\end{array}$ & $\begin{array}{l}1 \\
2 \\
1 \\
1^{1)}\end{array}$ & 6 \\
\hline
\end{tabular}

1) $2 \%$ or more pollen grains in one pollen mother-cell.

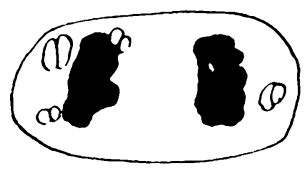

Text-fig. 12. Pollen mother-cell of $\mathrm{I}_{3}$ plant (Pedigree 12), bivalent chromosome garniture (black) at anaphase and four univs. (blank) in longitudinal division. 
Y. In this, the female parent of $F_{1}$ plants had the single flower, the entire, red petal with a white patch at the base. The $F_{1}$ plants were back-crossed with pollen of $P$. somnif $\mathrm{crum}$ var. glabrum which had the single flower and the laciniated red petal with a purple patch at the basc. Four (13-16) pedigrces were derived from them.

Pedigree 13. $F_{3}$ plants $41,15,33\left(S_{1}\right.$ of $F_{2}$ plant $41,15,15,5$, whose flower was the same as that of $F_{1}$ plant).

The external characters of 32 incividuals examined are shown in Table 21.

Table 21

\begin{tabular}{|c|c|c|}
\hline Character & $\begin{array}{c}\text { Red petal with a } \\
\text { purple patch }\end{array}$ & $\begin{array}{c}\text { Red petal with a } \\
\text { white patch }\end{array}$ \\
\hline Single ........ $\left\{\begin{array}{l}\text { Laciniated } \\
\text { Entire }\end{array}\right.$ & 14 & 5 \\
10 & 1 \\
\hline
\end{tabular}

In addition to those in Table 21 there was one indivirlual which had flower resembled that of $F_{1}$ plant.

Purple patch: white patch $=24: 6$

Laciniated : entire $=19: 11$

The results of karyological examination in the meiotic phase of pollen mother-cells in 13 individuals are as follows:

lable 22

\begin{tabular}{|c|c|c|c|}
\hline I)ivision & Chromosome number & $\begin{array}{l}\text { Number of in- } \\
\text { dividual plants }\end{array}$ & Total \\
\hline Regular & $\begin{array}{l}11 \text { bils. } \\
\text { Undeterminerl }\end{array}$ & $\begin{array}{l}6 \\
3\end{array}$ & 9 \\
\hline Irregular & $\begin{array}{l}11 \text { bivs. }+2 \text { univs. } \\
11 \text { bivs. }+1 \text { univ. } \\
\text { Undetermined }\end{array}$ & $\begin{array}{l}1 \\
1 \\
2^{1)}\end{array}$ & 4 \\
\hline
\end{tabular}

1) One of them had $2+$ pollen grains in one pollen mother-cell.

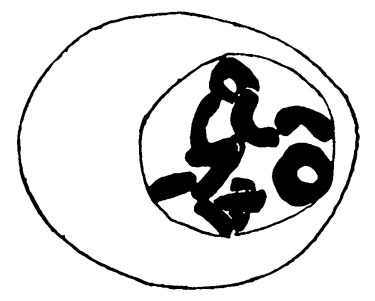

Text-fig. 13. Pollen mother-cell of $\mathrm{F}_{3}$ plant (Pedigree 13) in diakinesis; 11 birs. are seen. 
Pedigree 14. $\mathrm{F}_{3}$ plants $41,15,39\left(\mathrm{~S}_{1}\right.$ of $\mathrm{F}_{2}$ plant $41,15,15,11$, whose flower was the same as that of $F_{1}$ plant).

The external characters of 24 individuals examined are shown in Table 23.

Table 23

\begin{tabular}{|c|c|c|}
\hline Character & $\begin{array}{c}\text { Rel petal with a } \\
\text { purple patch }\end{array}$ & $\begin{array}{c}\text { Red petal with a } \\
\text { white patch }\end{array}$ \\
\hline Single........ & 3 & 1 \\
laciniated & 16 & 4 \\
\hline
\end{tabular}

Purple patch: white patch $=19: 5$

Laciniated : entire $=4: 20$

The resuits of karyological examination in the meiotic phase of pollen mother-celis in 4 individuals are as follows:

Table 24

\begin{tabular}{|c|c|c|c|}
\hline I)ivision & Chromosome number & $\begin{array}{l}\text { Number of in- } \\
\text { dividual plants }\end{array}$ & Total \\
\hline Regular & $\begin{array}{l}11 \text { bivs. } \\
\text { Indetermined }\end{array}$ & $\begin{array}{l}3 \\
1\end{array}$ & 4 \\
\hline
\end{tabular}

Pedigree 15. $F_{3}$ plants $41,15,41\left(S_{1}\right.$ of $F_{2}$ plant $41,15,15,18$, whose flower was the same as that of $F_{1}$ plant).

The external ciraracters of the flowers of 23 individuals examined are shown in Table 25 .

Table 25

\begin{tabular}{|c|c|c|}
\hline Character & $\begin{array}{c}\text { Red pstal with a } \\
\text { purple patch }\end{array}$ & $\begin{array}{c}\text { Red petal with a } \\
\text { white patch }\end{array}$ \\
\hline Single........ $\left\{\begin{array}{l}\text { laciniated } \\
\text { entire }\end{array}\right.$ & 11 & 1 \\
& 7 & 3 \\
\hline
\end{tabular}

In addition to those which are showing in Table 25 , there was one which had the flower resembled that of $F_{1}$.

The results of karyological examination in the meiotic phase of pollen mother-cells in 8 individuals are as follows: 
Table 26

\begin{tabular}{|c|c|c|c|}
\hline I)ivision & Chromosome number & $\begin{array}{l}\text { Number of in- } \\
\text { dividual plants }\end{array}$ & 'lotal \\
\hline Regular & $\begin{array}{l}11 \text { bivs. } \\
\text { L'ndetermined }\end{array}$ & $\begin{array}{l}1 \\
1\end{array}$ & 2 \\
\hline Irregular & $\begin{array}{l}11 \text { bivs. }+2 \text { or } 3 \text { univs. } \\
11 \text { bivs. }+1 \text { univ. } \\
\text { Endetermined }\end{array}$ & $\begin{array}{l}1 \\
2 \\
411\end{array}$ & 6 \\
\hline
\end{tabular}

1) One of them had 2-4 pollen grains in one pollen mother-cell.

Pedigree 16. $F_{3}$ plants $41,15,43\left(S_{1}\right.$ of $F_{2}$ plant $41,15,15,26$, whose flower was similar to that of $F_{1}$ plant).

The external characters of the flowers of 17 individuals examined are shown in Table 27.

Talsle 27

\begin{tabular}{|c|c|}
\hline Chracter & Number of indivirluals \\
\hline Red petal $\left\{\begin{array}{l}\text { with a purple patch } \\
\text { with a white patch }\end{array}\right.$ & 16 \\
\hline
\end{tabular}

The results of karyological examination in the meiotic phase of pollen mother-cells in 6 individuals are as follows:

lable 29

\begin{tabular}{|c|c|c|c|}
\hline I)ivision & Chromosome number & $\begin{array}{l}\text { Number of in- } \\
\text { dividual plants }\end{array}$ & 'lotal \\
\hline Regular & $\begin{array}{l}11 \text { bivs. } \\
\text { Undetermined }\end{array}$ & $\begin{array}{l}2 \\
1 \\
-\end{array}$ & 3 \\
\hline Irregular & $\begin{array}{l}11 \text { bivs. }+3 \text { univs. } \\
11 \text { bivs. }+2 \text { univs. } \\
\text { Endetermined }\end{array}$ & $\begin{array}{l}1 \\
1 \\
1\end{array}$ & 3 \\
\hline
\end{tabular}

1) 2-t or more pollen grains in one pollen mother-cell.

a

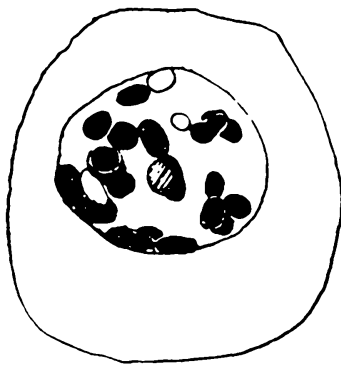

b

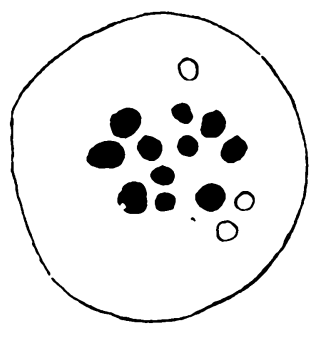

c

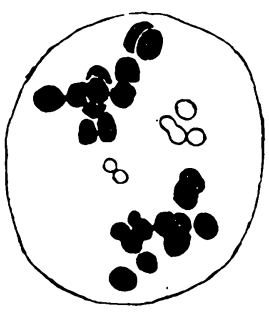

Text-fig. 14. 3 pollen mother-cells of $F_{: a}$ plants (Pedigrce 16). a, diakinesis, 
11 bivs. (black) and 3 univs. (blank) seen; b, later stage, 11 bivs. at the equator and 3 univ. scattered outside of them; c, still later stage, chromosome garniture derived from bivs. in anaphase and univs. in metaphase.

YI. In this, the female parent of $F_{1}$ plant had the single flower, the laciniated, red petal with a purple patch at the base, but it was hetero-individual which had to segregate into four different kinds of individuals; 1 , red petal with a white patch, 2, red petal with purple patch, 3, pale purple petal with a deeper purple patch, 4, white petal. The $F_{1}$ plants were back-crossed with the pollen of a P. som nif crum which had single flower, the laciniated, red petal with purple patch at the base. Three pedigrees (17-19) were derived from them.

Pedigree 17. $F_{3}$ plants $41,15,36\left(S_{1}\right.$ of $F_{2}$ plant $41,15,15,8$, whose flower was the same as that of $F_{1}$ plant).

The external characters of the flowers of 41 individuals were examined, and found that all individuals had the single flower and the laciniated petals, and the number of individuals which had petals of different colors are shown in Table 29.

Table 29

\begin{tabular}{|l|c|}
\hline \multicolumn{1}{|c|}{ Character } & Number of individuals \\
\hline 1. Red petal with a purple patch & 38 \\
2. Red petal with a white patch & 1 \\
3. Deep purple patch & 2 \\
\hline
\end{tabular}

The results of karyological examination of pollen mother-cells in 13 individuals are as follows :

Table 30

\begin{tabular}{|l|l|l|c|}
\hline \multicolumn{1}{|c|}{ Division } & \multicolumn{1}{|c|}{ Chromosome number } & $\begin{array}{l}\text { Number of in- } \\
\text { dividual plants }\end{array}$ & Total \\
\hline Regrnlar & $\begin{array}{l}11 \text { bivs. } \\
\text { Uniletermined }\end{array}$ & 6 & 4 \\
\hline \multirow{2}{*}{ Irregular } & $\begin{array}{l}11 \text { bivs. }+2 \text { univs. } \\
\text { Lndeterminerl }\end{array}$ & 10 & 3 \\
\hline
\end{tabular}

1) 2-4 or more pollen grains found in one pollen mother-cell.

Pedigree 18. $F_{3}$ plants $41,15,46$ ( $S_{1}$ of $F_{2}$ plant $41,15,15,46$, whose flower was similar to that of $F_{1}$ plant).

The external characters of the flowers of 24 individuals exa. mined are shown in Table 31. 
Table 31

\begin{tabular}{|l|c|}
\hline \multicolumn{1}{|c|}{ Character } & Number of individuals \\
\hline 1. $\begin{array}{l}\text { Red petal with a purple p.tch, } \\
\text { laciniated ; single. }\end{array}$ & 22 \\
2. Pale purple petal with a deeper \\
$\begin{array}{l}\text { purple patch, laciniated; single. } \\
\text { Deep purple petal, laciniaterl; } \\
\text { single. }\end{array}$
\end{tabular}

The results of karyological examination in the meiotic phase of pollen mother-cells in 7 individuals are as follows :

Table 32

\begin{tabular}{|l|l|c|c|}
\hline \multicolumn{1}{|c|}{ Division } & \multicolumn{1}{|c|}{ Chromosome number } & $\begin{array}{c}\text { Number of in- } \\
\text { dividual plants }\end{array}$ & Total \\
\hline Regular & 11 bivs. & 5 & 5 \\
\hline Irregular & $\begin{array}{l}11 \text { bivs. }+1 \text { univ. } \\
\text { Undetermined }\end{array}$ & $\begin{array}{l}1 \\
1^{1}\end{array}$ & 2 \\
\hline
\end{tabular}

1) 2-4 pollen grains were found in one pollen mother-cell.

Pedigree 19, $\mathrm{F}_{3}$ plants $41,15,50\left(\mathrm{~S}_{1}\right.$ of $\mathrm{F}_{2}$ plant $41,15,15,57$, whose flower was similar to that of $F_{1}$ plant).

The external characters of the flowers of 20 examined individuals of $F_{3}$ plants were of the same, and they had the single flower, and the laciniated red petal with a purple patch.

The results of karyological examination in the meiotic phase of pollen mother-cells in 16 individuals are as follows :

Table 33

\begin{tabular}{|l|l|c|c|}
\hline \multicolumn{1}{|c|}{ I)ivision } & \multicolumn{1}{|c|}{ Chromosome number } & $\begin{array}{c}\text { Number of in- } \\
\text { dividual plants }\end{array}$ & Total \\
\hline Regular & 11 bivs. & 4 & 4 \\
\hline Irregular & $\begin{array}{l}11 \text { bivs. }+1 \text { univ. } \\
11 \text { bivs. }+2 \text { univs. }\end{array}$ & 1 \\
\hline
\end{tabular}

\section{Discussion}

\section{A. Irregular behavior in meiosis}

a. The number of gemini and univalent chromosomes.

1. $F_{1}$ generation. There were found only three as a rule, but sometimes four gemini and 12 or 10 unpaired chromosomes. This is very different from the case in $F_{1}$ plant, $P^{\prime}$. somniferum var. glabrum $\times$ 
oricntali. In the latter the number of gemini formed are equal to the chromosome number of the one parent winich had small chromosome number, i. e. $11 \mathrm{in} P$. somnif (rum var. glabrum, while in the former the number of gemini formed are less than the chromosome number of $P$. nudicaule, which has 7 haploid chromosomes, the basic unit number among Papaicr species.

Nany authors believe that the gemini formation in meiotic phase is due to the affinities between the chromosomes from both parents, but some experiments, e. g. BORGFistam (1922), SAkAMURA and STow (1925), show that the external factors, e. g. temperature, may induce it. The presenit writer also observed the similar case in the course of the research; but still she would enphasize that the affinities betwecn chromosomes is the main factor in nature and will determine the gemini number in hybrid plants.

2. $F_{2}$ generation. In the three cases examined there were 11 gemini and 7,6 , and 5 univalent chromosomes.

3. $\mathrm{F}_{3}$ generation. Table 34 gives the frequency distribution of

Table 37

\begin{tabular}{|c|c|c|}
\hline $\begin{array}{l}\text { Name of } \\
\text { pedigree's }\end{array}$ & $\begin{array}{l}\text { Number of individuals } \\
\text { with } 11 \text { bivs. }\end{array}$ & $\begin{array}{l}\text { Number of molividuals } \\
\text { with more than } 11 \\
\text { bivs. and additional } \\
\text { chromosomes }\end{array}$ \\
\hline 3 & 7 & 0 \\
\hline 7 & 4 & 0 \\
\hline 14 & 3 & 0 \\
\hline 1 & 9 & 2 \\
\hline 2 & 6 & 2 \\
\hline 4 & 0 & 4 \\
\hline 5 & 4 & 2 \\
\hline 6 & 6 & 7 \\
\hline 8 & 3 & 3 \\
\hline 9 & 4 & 1 \\
\hline 10 & 5 & 1 \\
\hline 11 & 2 & 5 \\
\hline 12 & 4 & 4 \\
\hline 13 & 6 & 3 \\
\hline 15 & 1 & 3 \\
\hline 16 & 2 & 2 \\
\hline 17 & 6 & 2 \\
\hline 19 & .5 & 1 \\
\hline \multirow[t]{2}{*}{19} & 4 & 2 \\
\hline & 81 & 44 \\
\hline
\end{tabular}


chromosome number among the above 19 mentioned pedigrees of mentioned $\mathrm{F}_{3}$ generation.

As it is seen in the above table, in 3 among 19 pedigrees all individuals had 11 bivalent chromosomes like $P$. somnif crum var. glabrm, and 67 out of 111 individuals belonging to the 16 remaining pedigrees had 11 bivalent chromosomes also, and the remaining 44 individuals more than 11 bivalents or more than bivalents, and a number of univalents.

Table 35 shows the frequency distribution of chromosome number in individuals with 11 bivalents and a number of additional chromosomes.

Table 35

\begin{tabular}{|c|c|}
\hline Number of chromosomes & Number of individuals \\
\hline 11 hivs. +1 univ. & 19 \\
\hline 11 bivs. +2 univs. & 18 \\
\hline 11 hivs. +3 univs. & 4 \\
\hline 11 bivs. +4 univs. & 3 \\
\hline 11 bivs. +1 biv. +2 univs. & 1 \\
\hline 11 hivs. +1 biv. +1 univ. & 1 \\
\hline Total & 44 \\
\hline
\end{tabular}

By comparing the chromosome numbers in the three generations $F_{1}, F_{2}, F_{3}$ and the structure of gemini we may conclude

1. Successive diminutions of the number of univalent chromosomes.

2. Restitution of 11 bivalent chromosomes in $F_{2}$ generation.

3. Fixation of individuals with 11 bivalents in $\mathrm{F}_{3}$ generation.

4. Absence of parasyndetic figure in $F_{1}$ generation and its appearance in $\mathrm{F}_{2}$ generation.

5. Considerable increase of the number of gemini in $F_{3}$ generation.

The simultaneous restitution of the appearance of the number of somnif crum chromosomes and parasyndetic figures indicate the stronger affinity between the allelochromosomes ${ }^{1)}$ and their number

1) The term allelochromosome has been introduced by Irof. K. Fujn in his course of lectures on genetics for the academic year 1919-20 in the Faculty of Science, Tokyo Imperial University, in place of generaly used term "homologous chromosome," especially for the case of hybrid plants, in which this term conveys the idea of chromosomes carrying allelogenes (differential genes concerned in the development of allelomorphic characters). As the antonym or allelochromosome to denote a homozygous pair of chromosomes, he proposed the term homochromosome. 
may determine the number of gemini in the meiosis. KIHARA (1924) observed the restitution of the chromosome numbers of both parent plants in individuals of $\mathrm{F}_{4}$ generation and the stableness of meiotic phase in pentaploid hybrid of Triticum species. In the present case of my Papaver hybrid, there is no restitution of the smaller number of chromosomes characteristic to one of the parents, while individuals with increased number of chromosomes appear in addition to the restitution of the larger number of chromosomes characteristic to the other parent.

b. Irregular cell division. All individuals in $F_{1}$ and $F_{2}$ generations in these experiments, as far as observed, showed irregular cell division in meiosis of pollen mother-cells, but such individuals diminished in number in $\mathrm{F}_{3}$ generation with the elimination of univalent chromosomes anong them as is shown in the following table :

Table $36 \quad\left(\mathrm{~F}_{3}\right.$ individuals $)$

\begin{tabular}{|c|c|c|}
\hline $\begin{array}{l}\text { Name of } \\
\text { pedigree }\end{array}$ & $\begin{array}{l}\text { Number of individuals } \\
\text { with regular meiotic } \\
\text { division }\end{array}$ & $\begin{array}{l}\text { Number of individuals } \\
\text { with irreg. meiotic } \\
\text { division }\end{array}$ \\
\hline 1 & 10 & 3 \\
\hline 2 & 10 & 3 \\
\hline 3 & 7 & 0 \\
\hline 4 & 1 & 5 \\
\hline 5 & 8 & 1 \\
\hline 6 & 6 & 7 \\
\hline 7 & 6 & 0 \\
\hline 8 & 3 & 3 \\
\hline 9 & 5 & 1 \\
\hline 10 & 6 & 2 \\
\hline 11 & 2 & 6 \\
\hline 12 & 5 & 6 \\
\hline 13 & 9 & 5 \\
\hline 14 & 4 & 0 \\
\hline 15 & 2 & 6 \\
\hline 16 & 3 & 3 \\
\hline 17 & 9 & 4 \\
\hline 18 & 5 & 2 \\
\hline \multirow[t]{2}{*}{19} & 4 & 2 \\
\hline & Total & Total \\
\hline
\end{tabular}

Among these 59 individuals, which show irregular divisions in meiosis, there were about 7 individuals, in which some pollen 
mother-cells divided only once in meiosis; in some pollen mothercells, only one of two daughter nuclei derived from the heterotypic division divided homotypically; and in others normal meiotic division took place. The result is the formation of $2-4$ pollen grains in a pollen mother-cell instead of constantly 4 pollen grains. In these cases the pollen mother-cells contained 11 bivalent chromosomes and their behavior in heterotypic division was regular, so that the pollen grains formed through one division only had 22 haploid chromosomes. Some of $\mathrm{F}_{4}$ individnals. which were derived from such as the latter, are expected to be tetraploid or triploid, but unfortunately these $\mathrm{F}_{3}$ plants are mostly sterile, so that such a tetraploid-plants will be very rare.

$B$. Cytological findings in relation to genetics. The yellowish orange color in the male parent dominated to all other different colors in the flower of $P$. somniferum var. glabrum, namely white, purple, and red, so that all $F_{1}$ plants are uniform.

More than 60 back-crossed $F_{2}$ individuais had similar flowers to that of $F_{1}$ plant except one, and among more than $500 \mathrm{~F}_{3}$ plants only 6 individuals had similar flower to that of $F_{1}$ plant, but other individuals had flower similar to that of $P$. somniferum $\mathrm{L}$. var. glabrum Bors. In their interspecific hybrids of Nicotiana, GOODSPEED and CIAUSEN (1922) got individuals identical with each parent in the back-crossed $F_{1}$ generation by back-crossing with each parent pollen to $F_{1}$ plants, and all their offsprings were found identical to their parents.

In the present case almost of all back-crossed $F_{2}$ individuals resembled the $F_{i}$ plants, but not $P$. somniferum var. glabrum.

These eliminations of male characters in successive generations take place simultaneously with the eliminations of univalent chromosomes among them, which indicates that the genes for the eliminated character of the male plant was represented in some univalent chromosomes which dropped off in the process of meiosis generally in that of $F_{2}$ plant, and rarely in $F_{1}$ plants. Thus the plants in following generations tend to return to $P$. somniferum L. var. glabrum Bors. generally.

The segregation of the allelomorphs i. e. $\frac{\text { "laciniated }}{\text { entire }}, \frac{\text { single }}{\text { double }}$, $\frac{\text { purple patch }}{\text { white patch }}$, etc. in $\mathrm{F}_{3}$ generation is not so regular as may be expected in the. Mendelian hybrids among the races in $P$. somniferum L. var. glabrum BoIs., e.g. 7 purple patch : 29 white 
patch, 6 laciniated : 19 entire, 3 laciniated : 29 entire, etc. The ratios indicate the dominancy of entire to laciniated, and of white to purple patch. These $\mathrm{F}_{3}$ plants are however as phenotype $P$. somniferum L. var. glabrum BoIs., in which the character entireness in petal is recessive. $F_{4}$ generation which is now in seedling forms, will determine the point in course of the year. It may be conjectured, however, that the presence of supernumeral univalents from either side of parents or interchanges of genes concerning these characters, between $P$. somniferum L. var. glabrum Bors. and $P$. nudicaule L., which might have taken place during the successive generations $\mathrm{F}_{1}-\mathrm{F}_{3}$, may have caused the reversal of dominancy in $P$. somniferum L. var. glabrum Bors.

There was one individual whose flower had red spots on the pink petals among $F_{3}$ plants. This character was not observed in previous generations as far as we know. Whether it is due to a chromosomal mutant must be left undecided.

\section{SumMary}

1. In $\mathrm{F}_{1}$ plant of Papaver somniferum L. var. glabrum BoIs. $\times P$. nudicaule $\mathrm{L}$. the orange color of the petal of $P$. nudicaule dominated over the color of the petal of P. somniferum var. glabrum, hairy to glaucous, entire to laciniated, single to double, but perennial was recessive to annual.

2. Such dominant characters were eliminated in almost all individuals of $\mathrm{S}_{4}$ plants of back-crossed $\mathrm{F}_{2}$ plants, and the characters of $P$. somniferum var. glabrum were restituted among them.

3. The chromosome number of $F_{1}$ plants was 18 , viz. the sum of the haploid chromosome numbers of both parents. Among these chromosomes 6 or 8 chromosomes only mated to form gemini in the meiosis of the pollen mother-cells and the rest remained as unpaired univalent chromosomes.

3. Out of 3 examined individuals of back-crossed $F_{2}$ plant, one had 11 bivalent chromosomes and 7 univalent chromosomes, another had 11 bivalent and 6 univalent chromosomes, and the remaining one 11 bivalent and 5 univalent chromosomes.

4. The univalent chromosomes were eliminated largely in $\mathrm{F}_{3}$ individuals. Out of 122 individuals, in which the chromosome numbers were determined, 82 individuals showed 11 bivalent chromosomes only.

5. In 42 individuals which had more than 11 bivaient chromosomes, the largest number of univalent chromosomes was 4 . 
6. The parallel eliminations between the paternal characters and univalent chromosomes, and parallel restitution between the maternal characters and parasyndesis indicate that the univalent chromosomes belonged mostly to $P$. nudicaule $\mathrm{L}$.

7. The large deviation in the segregation of $\mathrm{F}_{3}$ plants may be ascribed to the irregular behavior of chromosomes in meiosis, but in addition the writer expects interchanges of genes concerning these characters.

8. There was one plant whose petals had red spots which never observed in their previous generations.

In closing the writer wishes to express her cordial thanks to Professor K. FUJII for the valuable materials given her for this experimental study and important advices throughout the course of the work.

February 1927

Botanical Institute, Faculty of Science Tokyo Imperial University

\section{BibliogRAPHY}

BEI,ING, J. (1921) The origin of chromosomal mutations in Uz'ularia. Journ. Genetics. Vol. 15. pp. 245-266.

BELLING, J. (1923) The attraction between homologous chromosomes. Eugenics, genetics and the family. Vol. 1. pp. 84-85.

BELIJNG, J. and BLAKESI,EE, A.F. (1926) On the attachment of non-homologous chromosomes at the reduction division in certain 25 -chromosome Daturas. Proc. nat. Acad. Sci. Vol. 12.

Borgenstam, E. (1922) Zur Zytologie der Gattung Syringa. Arch. f. Bot. Bd. 17.

Clausen, J. (1926) Genetical and cytological investigations on Viola tricolor I. and $V$. arvensis MURR. Hereditas. Vol. 8.

GoodspeED, T. H. and ClaUSEN, R. E. (1922) Interspecific hybridization in $\mathrm{Ni}$ cotiana. I. On the results of backcrossing the $\mathrm{F}_{1}$ sylvestris-Tabacum hybrids to sylvestris. Univ. of Calif. Pub. in Bot. Vol. 2. No. 1. pp. 1-30.

KIHARA, H. (1924) Cytologische und genetische Studien bei wichtigen Getreidearten mit besonderer Rücksicht auf das Verhalten der Chromosomen und die Sterilität in den Bastarden. Mem. of Coll. Sci. Kyoto Imp. Univ. Ser. B. No. 1. Art. 1.

IJJUNGDAHL, H. (1924) Über die Herkunit der in der Meiosis konjugierenden Chromosomen bei Papaver-Hybriden. Sv. Bot. Tidsk. Bd. 18. H. 2. S. 279-291.

Sakamura, T. und STow, I. (1926) Über die experimentell veranlasste Entstehung von keimfähigen Pollenkörnern mit abweichenden Chromosomenzahlen. Japanese Journ. of Bot. Vol. 3. No. 2.

TAHARA, M. (1915) The chromosomes of Papaver(Japanese). Dot. Mag. Tokyo. Vol. 29. pp. 257.

TAYLOR, W. R. (1924) The smear method for plant cytology. Bot. Gaz. Vol. 78. pp. $236-238$.

YASUI, K. (1921) On the behavior of chromosomes in the meiotic phase of some artificially raised Papaver hybrids. Bot. Mag. Tokyo. Vol. 35. pp. 154-167. 